\title{
A blog hatása a politikai kommunikációra egy fontos politikai blog tükrében
}

D

A szerző tanulmányának bevezetésében a blog fogalmát ismerteti, az interneten folyó kommunikáció kontextusában. A témát két részre bontva fejti ki, mondanivalóját a magyar miniszterelnök blogja köré építve fel. Az első részben az üzleti világra koncentrál, melynek számos innovációját a politika is megpróbálja adaptálni a maga céljaihoz. A második részben a blog által a politikai kommunikáció számára kínált lehetőségeket teszi vizsgálat tárgyává.

Kulcsszavak: blog, Gyurcsány-blog, politikai kommunikáció

\section{Szerzői információ:}

Ughy Márton

Az ELTE jogi karának jogász és politológus hallgatója. 2004-ben érettségizett az ELTE Apáczai Csere János Gyakorlógimnáziumában, négy nyelven beszél. A 2007. évi Országos Tudományos Diákköri Konferencia politikatudományi szekciójában hetedik helyezést ért el. Elsődleges kutatási területe a politikai kommunikáció. Itt közölt cikke az elsô szakmai publikációja.

E-mail: marton.ughy@gmail.com

Így hivatkozzon erre a cikkre:

Ughy Márton. „A blog hatása a politikai kommunikációra egy fontos politikai blog tükrében”. Információs Társadalom VII, 3. szám (2007): 102-114.

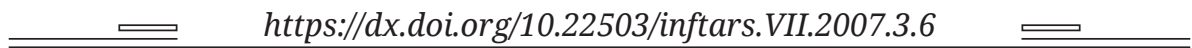

A folyóiratban közölt müvek

a Creative Commons Nevezd meg! - Ne add el! - Így add tovább! 4.0

Nemzetközi Licenc feltételeinek megfelelöen használhatók. 
Ughy Márton

\section{A blog hatása a politikai kommunikációra egy fontos politikai blog tükrében}

\section{Bevezetés}

Magyarország jelenleg leghíresebb politikusi blogja a Gyurcsány-blog, melynek elkészítése a miniszterelnök bevallása szerint „2005 ôsze óta volt napirenden”, 1 az első bejegyzés mégis 2006. január 31-én kelt. A kormányfő́ webnaplójának az Alapítvány a Modern Baloldalért honlapja, a www.amoba.hu ad otthont. A magyar politikusok közül nem Gyurcsány Ferenc lépett be először az ún. blogoszférába, és a 2006. évi országgyúlési és önkormányzati választások kampányai megmutatták, hogy nem ő volt az utolsó sem. Magyarországon mégis ez a blog híresült el leginkább, ami nyilvánvalóan a miniszterelnöki pozíció prominens mivoltának, a kampánynak és az ezekhez kötődő reklámtevékenységnek köszönhetô.

A látogatók többsége biztos szavazó, akik mindennap olvassák a miniszterelnök bejegyzéseit, konstruktív hozzászólásaikkal buzdítják, és a személye elleni támadások esetén mellette szólalnak fel. Politikailag nyugodtabb idókben a blog adta nyilvánosságban egyszerúen megbeszélik a nap eseményeit, recepteket és eszméket cserélnek, társalgást folytatnak, érvelnek. Ezek az emberek - valószínúleg nem is tudatosan - egy jelentôs részben fiatalokból álló virtuális miniközösséget hoztak létre és tartanak fenn.

Mindez a politikai kommunikáció egyik forradalmian új eszközének felhasználására nyújt magyar példát. Az internet paradigmatikus kérdéseit tekintve, a blogok terjedése akár paradigmaváltást is elốre vetíthet (Kline-Burstein, 2005: xiv). Az adott példa esetében a blog nemcsak emberközelbe hozza a miniszterelnök egyébként szinte elérhetetlen személyét, hanem egyúttal bizonyos intimitást is kölcsönöz az író és olvasói között létrejövố kapcsolatnak, s itt a kapcsolat szó a leglényegesebb. Ennek a kapcsolatnak egyik kulcsfontosságú eleme a blog szerzôje és olvasói közötti kölcsönhatás: a miniszterelnök és választói megkerülik a különböző médiumok szerkesztốit, a bürokrácia tengerét, a különféle szúróket, és közvetlenül lépnek kapcsolatba egymással. Természetesen ez a kapcsolat - mint késóbb látni fogjuk - sántít, és legtöbbször csupán szimbolikus.

Bármit gondolunk is róla, be kell látnunk, hogy a blog valami újat hozott a politikába - ahogy a gazdaságba, a kultúrába és az élet számos más területére is. Magyarországon - a rendszeres internethasználók viszonylag alacsony száma miatt - ennek még nem érezhetố olyan erốs hatása, mint az USA-ban, mégis fontos tudnunk róla, hiszen az Egyesült Államokban a politikai blogok megjelenése bombaként hatott. Masszív változásokat idézett elő nagyvállalatok, pártok, társadalmi szervezetek kommunikációjában,

${ }^{1}$ A blog-írásról, Gyurcsány Ferenc blogján. http://blog.amoba.hu/blog-3.php?oid= T912507b436e6c84308db65d43491b94 (Letöltés ideje: 2006. október 20.) 
közösségek szervezésében és kampányok alakításában. A blog a 2004. évi elnökválasztási kampány egyik legmeghatározóbb elemévé vált, melynek felhasználásával a szavazók névtelen jelölteket emeltek fel vagy küldtek a süllyesztốbe, végeredményben pedig a republikánusok többek között a blognak is köszönhetően nyerték meg a választást. A közelmúltban pedig a kiélezett 2007. évi franciaországi elnökválasztási kampányban is erôs blogolás volt megfigyelhetô.

Témám kifejtését a blog fogalmának és rövid történetének bemutatásával kezdem, majd rövid kitérót teszek az üzleti világba, ahol már hosszabb ideje alkalmazzák a webnaplókat, ezért nagyobb tapasztalattal rendelkeznek kiaknázásukat illetően. A magyar miniszterelnök webnaplója és a multinacionális cégek, a marketing és a politikai kommunikáció közötti párhuzamok és hasonlóságok körvonalazása után rátérek az internetes politikai kommunikáció sajátosságaira és a bloggal folytatott kampányra a Gyurcsány-blog tükrében. Vizsgálatom a miniszterelnöki webnapló létrejöttétól 2006. október 23-ig tartott: ebben a szúken kilenc hónapos idôszakban kampány elốtti, alatti és utáni periódusok váltották egymást, sốt válságkezelési kísérletre is volt példa.

\section{1. $A B \log$}

Biz Stone, az „ősbloggerek” egyike így teszi fel - és így válaszolja meg rögtön - azt a kérdést, hogy mi is az a blog és a blogolás: „[Vajon] ... önkifejezés, személyes kiadvány, napló, amatốr zsurnalisztika, a legnagyobb bomlasztó technológia az e-mail óta, online közösség, alternatív médiavilág, diákoknak való stúdium, marketingstratégia, tudás-menedzsment, köldökbámulás, orvosság az unalom ellen, írásstílus, e-mail mindenkinek, szeszély, válasz az írástudatlanságra, online perszóna, társadalmiháló-szövés, önéletrajz-takarmány, telefonkamerás képvilág, vagy valami olyasmi, amit el kell rejteni anyuka elól? - Mindez, és még több" (Stone, 2004: 34).

\subsection{A blog fogalma és története}

Bár a magyar internetpenetráció az EU-n belül csak Máltával, Görögországgal és Ciprussal veheti fel a versenyt, és nálunk internetszegényebb ország már csak a lengyeleké, ${ }^{2}$ azért manapság már nincs olyan, aki az internet mibenlétével ne lenne tisztában: a világméretú számítógép-hálózatról van szó, melynek gyakorlatilag bárki a tagja lehet. Ezen a világhálón belül a blog olyan honlap, melyen egy vagy több szerzó által írt és publikált bejegyzések fordított kronológiai sorrendben jelennek meg.

Ebból következik, hogy minden blogra jellemző három alapvető dolog: a kronológia, a rendsæeresség (naponta, hetenként vagy bármilyen más rendszer szerint történő megjelenés) és az egy (vagy néhány) témára való összpontosítás (Stone, 2004: 39). Ugyanakkor a blog nem csupán közlemények halmaza, hiszen tükrözi a szerzó (vagy

\footnotetext{
${ }^{2}$ European Union Internet Usage and Population Stats. Az Internet World Stats honlapján. http://www.internetworldstats.com/europa.htm (Letöltés ideje: 2006. október 23.)
} 
szerzốk) személyiségét, stílusát, és alapvetôen ettól lesz egy blog - ahogy bármely más írott alkotás is - jó vagy rossz, olvasható vagy olvashatatlan.

Kezdetben a világháló olyan kicsiny volt, hogy a webmesterek és rendszergazdák szó szerint naplót tudtak vezetni arról, hogy milyen új oldalak jöttek létre - a legelső protoblog is egy ilyen napló lehetett. Internetes keresốprogramok hiányában az efféle napló a felhasználó számára azzal a kifejezett haszonnal járt, hogy innen gyorsan és biztosan megtudhatta, ha valami újdonság jelent meg a hálón.

A kilencvenes évek elejétól kezdve azonban a világháló olyan tempóval kezdett el növekedni, amivel a rendszergazdák már nem tudtak lépést tartani, ezért csak a szívükhöz közelebb álló, az érdeklődési körükbe vágó vagy a viccesebb honlapokat vették fel internetes naplójukba, ezeket viszont nem egyszer kommentárokkal is ellátták. Noha a felhasználók száma ebben az idóben exponenciálisan növekedett, a honlapkészítés (és így a „blogolás” is) még egy darabig azon kevesek privilégiuma maradt, akik beszélték az internet gépi nyelveit.

A modern blog 1999-ben született. Ez volt az az év, amikor - a városi legenda úgy tartja - Peter Merholz (az első modern bloggerek egyike) megalkotta a blog kifejezést; és ugyancsak ez volt az az év, amikor létrejöttek az elsô könnyen használható blogalkalmazások, melyek segítségével már azok is hallathatták a hangjukat, akik nem rendelkeztek megfelelő programozási ismeretekkel. A bloggerek száma úgy nótt, ahogy néhány évvel azelốtt az internetezóké. Egy-két év alatt felfigyelt rájuk a blogoszférában „hagyományosnak" mondott média, de az innovatív vállalatok is érdeklődést mutattak a blogok iránt, mert meglátták bennük a lehetôségeket.

Mára már olyan világban élünk, ahol másodpercenként születik egy blog, és minden második másodpercben megszúnik egy másik. Hazánkban jelenleg több mint százezer, világszerte pedig több millió blog létezik.

\subsection{A politikai és a blogoszféra}

Az interneten folytatott elsô politikai kampányok jelentôs részére Amerikában került sor, ahol erre a viszonylag magas internetpenetrációnak köszönhető́n már közvetlenül az ezredforduló elôtt is volt lehetôség és igény. Az internet minden más kommunikációs eszköznél nagyobb mértékû́ interaktivitás ígéretével élt, a kilencvenes évek második felétôl kezdve megnôtt a honlapok jelentôsége, és tényleges szavazói igény támadt a pártok és jelöltjeik online megjelenésére. Először meg kellett teremteni a politikai honlapokat, majd azokat fenn is kellett tartani és idôról idôre frissíteni kellett. A politika egyre nagyobb teret kezdett hódítani a virtuális világban is. Fennállt ugyanis az a veszély, hogy aki nem halad a korral, az egyszerúen maradinak túnhet e-mail címek jelentek meg, melyeket „a választóknak, a választókért” hoztak létre. A politikai honlapok, sốt honlapcsaládok kezdetben - a párbeszédeket és közösségeket létrehozó nyilvános fórumok megjelenéséig, és néhol még azután is - online szórólapokra és brosúrákra hasonlítottak (Klotz, 2004: 69).

\footnotetext{
${ }^{3}$ Ma leteszi az esküt a kormány. Gyurcsány Ferenc blogján. http://blog.amoba.hu/blog-3.php?oid= T51f499784496a3685928f4b36f8cc83 (Letöltés ideje: 2006. október 19.)
} 
A modern blog megszületése után a blogoszféra gyorsan kiterjeszkedett a politika világára is, és viszont: a politika behatolt a blogoszférába. Idôvel - a való világhoz hasonlóan - a társadalom különféle szférái szinte áttekinthetetlenül összefonódtak a virtuális térben is. Ám a valódi blog-demográfiai robbanás a 2001. szeptember 11-i terrortámadás után következett be: a kialakult pánik okozta túlterhelôdés miatt a közvetítések leálltak, az online hírcsatornák képtelenek voltak lebonyolítani a forgalmat. Ezzel szemben a blogszolgáltatók a megnốtt látogatottság mellett is tudták folytatni a közvetítést. Ekkor jelentek meg az elsố „háborús blogok”, s ezekból fejlôdtek ki az ún. „politikai” - vagy „politizáló” - blogok mai formái.

A kifejezetten személyhez kötôdố „politikusi” blog kialakulása Howard Dean nevéhez köthető, aki 2003-ban esélytelen jelöltként vágott bele az Egyesült Államok elnökségéért folytatott kampányba - az egész országra kiterjedôen -, mindössze százezer dollárral és megközelítóleg ötszáz aktivistával. Kampányfónöke, Joe Trippi indította el a www.blogforamerica.com címú kampányblogot, melynek segítségével végül 45 millió dollárt gyűjtöttek össze, és több tízezer aktivistát sorakoztattak fel. A blogra azért volt szükségük, mert a sajtó eleinte nem engedte Deant szóhoz jutni, aki ezért egyszerúen megkerülte a hagyományos médiát, és közvetlenül a szavazókhoz fordult. Pontosabban: ezt a csapata tette meg, hiszen a webnaplót elsôsorban a stábja írta, és ráadásul nem rosszul, hiszen az végül hatékony közösségszervező portállá nő́tte ki magát. Ez a honlap volt a központja az országos kampánytevékenységnek, és ebból fejlődött ki egy egész honlapcsalád, melynek tagjait szerte az országban a lokális kampányok megszervezésére hozták létre az aktivisták és szimpatizánsok.

Az amerikai blogkampány annak köszönhette különleges ütóképességét, hogy a felbukkanó webnaplók ezrei egyszerre szolgáltak pénzgyưjtő állomásként, véleménykutató központként és mozgósítási csomópontként (Kline-Burstein, 2005: 15). A Trippi által megtervezett kampány precedensértékú volt: fél év alatt egy „komolytalan” aspiráns - legalábbis egy időre - a Demokrata Párt első számú jelöltjévé lépett elő. Dean blogja után nem sokkal minden „komoly” jelölt is „szerzett magának” egyet, még ha nem is feltétlenül tudták pontosan, hogy mi az.

Felmerülhet a kérdés persze, hogy a blogforamerica sikere mellett mégis miért ifj. George Bush foglalhatta el végül az Ovális Irodát. Tudni kell, hogy Dean kampánya -a webnaplók sikereit látva - túlságosan is erôsen támaszkodott a blogokra, s ez vezetett végül politikai „öngyilkosságához”. A blogok köré egy olyan „kemény mag” koncentrálódott, amely nem hagyta Deant szabadon politizálni, s ennek tagjai radikális elgondolásaikkal a saját jelöltjüket is túlharsogták.

A blog ereje és hatása tehát tagadhatatlan, ugyanakkor - mint minden eszközt - ezt is meg kell tanulni használni. Az üzleti világ a politikát évekkel megelớzve elkezdte felhasználni a blogokat a saját céljaira, s így már sokkal több tapasztalatra tett szert ezen a téren.

\section{2. Üzlet és politika - blogolás a siker érdekében}

„A blog evolúciós és nem revolúciós [jelenség], közölték velünk ismételten. Kilenc hónap kutatómunka és több mint 100 üzletember meginterjúvolása után mostanra meg vagyunk győződve arról, hogy a blog egy igen jelentôs revolúció eszköze; egy olyan 
forradalomé, amely a szó szoros értelemben megállíthatatlan, és amely meg fogja változtatni a nagyvállalatok és a célközönségük közti viszony egyensúlyi helyzetét" (ScobleIsrael, 2006: 228).

\section{1 Ü̇let és politika párhuzamai}

Az üzleti világban a marketing legváltozatosabb eszközeivel próbáljuk meg az embereket meggyớzni arról, hogy az általunk elóállitott terméket kell megvásárolniuk. El kell érnünk, hogy dollárjaikat a mi árucikkünk megvételére fordítsák.

A politika világában a politikai kommunikáció legváltozatosabb eszközeivel próbáljuk meg az embereket meggyốzni arról, hogy az általunk képviselt értékekre kell szavazniuk. El kell érnünk, hogy szavazódollárjaikat a mi jelöltünk megválasztására fordítsák.

Az üzleti és a politikai szakemberek egyaránt többé-kevésbé a fenti gondolatmenetnek megfelelốen próbálják felhasználni a blog eszközét is. Tudvalevô, hogy e két terület között a kommunikációs specialisták viszonylag szabadon mozognak, bár tény, hogy általában az elóbbinek a vívmányait próbálják az utóbbiba átültetni.

Ha a célok és az eszközök bizonyos szinten - mutatis mutandis - megegyeznek, ebból azt a következtetést vonhatjuk le, hogy kisebb-nagyobb módosításokkal szinte bármilyen stratégia és ötlet is átültethetố az egyik szférából a másikba. Az előzóekból pedig az következik, hogy nemcsak lehetséges, de hasznos is lehet, ha a már bóségesebb tapasztalatokkal rendelkezô üzleti világ példáin és tanulságain keresztül próbáljuk megközelíteni a kampányblogok logikáját.

\subsection{Létezik-e ideális blog?}

A következókben a Scoble-Israel szerzópáros könyvében az „,ideális üzleti blog” jellemzóire vonatkozóan közölt tizenegy ajánlást mutatom be. Az ajánlások az eszményi webnapló tartalmára vonatkoznak, ezért ismertetésükkel párhuzamosan beszámolok egy kiválasztott politikai blog (a Gyurcsány-blog) általam elvégzett tartalomvizsgálatáról és eredményeit összevetem az „ideális” mintával.

\section{Gyurcsány-blog bejegyzései}

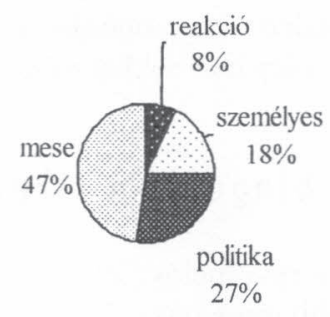

1. ábra. A Gyurcsány-blog bejegyzései 
Az elemzést a miniszterelnöki webnapló (2006. január 31. és október 23. közötti) 195 bejegyzésén végeztem el. Ezeknek a tartalmát négy, nagyrészt tisztán elkülöníthetố kategóriába soroltam. Az elsố a politika, ami a kormányfố konkrét politizálását, vagyis az „aktuálpolitikai” események vagy jelenségek véleményezését jelenti: mindaz ebbe a kategóriába került, amivel olvasóit a saját álláspontjáról próbálja meggyớzni. A második a személyes kategória: ide a családjáról és a személyes elfoglaltságai kapcsán felmerülő dolgokról általa közöltek tartoznak. A harmadik a reagálás: az olvasók hozzászólásaira, leveleire reagáló bejegyzésrészek köre. A negyedik és utolsó kategória a mese: itt látszólag „csak úgy” mesél miniszterelnöki mindennapjairól, vendégeiról és más élményeiról.

Minden egyes bejegyzést összesen tíz ponttal jellemeztem, amelyeket a négy kategória között osztottam el, annak függvényében, hogy a miniszterelnök miról mekkora terjedelemben szólt (pl. politika: 2 , személyes: 3 , reakció: 1, mese: 4, összesen: 10). Az így kapott eredményeket összesítve kaptam meg az 1. ábrán látható eredményt, ami a vizsgált idôszak összes bejegyzésére vonatkozik együttvéve.

Az alábbiakban a politikusi webnaplót az „üzleti siker” szempontjai szerint vizsgálom.

1. „Mielốtt az ember bármit tenne, érdemes néhány blogot elolvasni, belerázódni a blogolásba és a blogoszférába."

Az, hogy a miniszterelnök vagy bármely tanácsadója mennyire ismerte vagy ismerte meg azóta a blogoszférát, nem mérhető, annyi azonban megállapítható, hogy a miniszterelnöki napló a kezdeti 1000-1100 szavas, meglehetôsen hosszú bejegyzések helyett októberben már átlagosan 400-600 szavas írásokkal frissült, miközben mondandója egyszerúsödött és koncentrálódott. Ez a példaszerú blogok egyik olyan sajátossága, amit Scoble és Israel is megemlít - harmadik tanácsként.

2. Ha már nemcsak hallomásból ismerjük a blog múfaját, elkészíthetjük a magunkét is. Ehhez „válasszunk olyan címet és nevet, mellyel könnyuíszerrel megtalálnak”! Ha például nyomdával rendelkezünk, semmiképp ne egyszerúen „X. Y. blogja” vagy „N. N. naplója” legyen a címünk. Ha azt szeretnénk, hogy egyrészt a keresóprogramok az elsốk között találjanak ránk, másrészt a nyomdai szolgáltatásokat keresố felhasználó is ránk kattintson és ne másra, használjuk inkább a „Gutenberg blogja - egy nyomdász mindennapjai" címet.

A Gyurcsány-blog a http://blog.amoba.hu címen érhetô el, és neve „Amóba Blog”, amelyet bár jobban is elnevezhettek volna, a Google-próbát kiállta. A Google keresốjébe a „Gyurcsány-blog”, „Gyurcsány blogja”, illetve „Gyurcsány Ferenc blogja” kifejezéseket írva mindig az elsók között kaptuk a kormányfő́ naplóját.

3. Figyeljünk arra, hogy „,bejegyzéseink egyszerüek és koncentráltak legyenek”! Egy terjedelmes szöveg ijesztố tud lenni, a látogatók könnyen elveszíthetik érdeklődésüket, mert egyszerúen nincs türelmük végigolvasni.

$\mathrm{Az}$ 1. pontban elmondottaknak megfelelóen a nyár végére a Gyurcsány-blog is lerövidült, kevesebb idóbe telt a miniszterelnök gondolataival megismerkedni, ami Scoble és Israel álláspontja szerint mindenképpen pozitív vonás. 
4. „Stílusunk legyen megragadó!” Ha az olvasónak az az érzése támad, hogy a bloggal valamit rá akarunk eróltetni vagy azt csupán reklámként írjuk, lehetséges, hogy soha többé nem fog visszatérni hozzá. Nyilván támadnak benne kételyek, hogy egy üzletember vagy egy politikus ugyan mi másért akarna önmagáról és mindennapjairól blogolni, de ezeket viszonylag hamar el lehet oszlatni, ha érezhetóvé válik, hogy a szerzố valóban élvezi a blogolást.

5. „Mutassunk szakmai hozzáértést!” Ha már sikerült néhány pillanatnál tovább marasztalnunk egy látogatót, mutassuk meg, hogy valóban értünk ahhoz, amit csinálunk. A blog tartalmilag csak akkor lesz igazán jó, ha szerzóje egyszerre megragadó és hozzáértô, éppen ezért ezt a két pontot együtt érdemes tárgyalni.

Sajnos a miniszterelnök stílusának és hozzáértésének a hatását mérni lehetetlen, hiszen nem feltételezhetố, hogy olvasóinak számottevớ része elsôsorban vagy kizárólag a szerzó hozzáértố elóadásmódja, stílusa és nyelvezete miatt marad a blog rendszeres látogatója, mivel egy miniszterelnök esetében erősen érvényesül a prominens státusából adódó vonzerố is. Ez a „bulvárhatás” annyit tesz, hogy blogját sokan nem azért látogatják, mert arra kíváncsiak, hogy ô magánemberként mit mond, hanem a miniszterelnök, a politikai élet egyik elsố számú embere privátszférájába szeretnének betekintést nyerni. Ezzel a kormányfó is tisztában van, hiszen „újra megugrik a naplót látogatók és a hozzásะólók sæáma, amikor [...] inkább személyes jellegüek" írásai. ${ }^{3}$

6. „Adjunk lehetóséget az olvasónak a hozzászólásra!” Egyáltalán nem biztos, hogy „a vevốnek mindig igaza van”, de mindenképpen érdemes odafigyelni rá és tisztelettudóan végighallgatni.

A szóban forgó blog biztosítja a hozzászólás lehetôségét, amit a látogatók ki is használnak. A bejegyzésekhez a vizsgált időszakban átlagosan 535 hozzászólás érkezett.

7. „Legyiink elérhetóek!” Legalább egy e-mail cím vagy telefonszám legyen feltüntetve, ahol a szerzốt személyesen is el lehet érni, ha az olvasónak esetleg fontosabb mondanivalója van, nehogy az elvesszen a hozzászólások között.

A miniszterelnök a telefonszámát nem tette közzé, de elérhetô, hiszen e-mail címe nyilvános, és a blogjából kiderül, hogy a postáját rendszeresen - ritkábban személyesen, többnyire inkább munkatársainak a közvetítésével - figyelemmel kíséri.

8. „Meséljünk el egy történetet!” Ez a blog lényegéhez tartozik: mindenki elmondhatja a saját személyes történetét, és mindenki más éppen erre kíváncsi.

A kormányfó bejegyzéseinek majdnem a felét - ha nem is folyton a családjáról és a magánéletéról beszél, ahogy ez az 1. ábrán is látszik - a „mese” teszi ki. Mesél a Bécsbe tett utazásáról, annak eseményeiról, a találkozóról az ottani nagykövettel; mesél a miniszterelnök mindennapjairól, a kormány múködéséról, és nagyon sokszor tényleg csak mesél.

9. „Használjunk linkeket!” Ha valami nálunk nem elérhető, de megvan az esélye, hogy az olvasókat érdekli, tegyünk ki linkeket, mutassunk rá a világra!

Ennek a tanácsnak a politikában talán kevesebb értelme van, mint az üzleti világban, hiszen az eredeti indoklás szerint azért érdemes „linkelni”, mert ha valamivel a sa- 
ját üzletünk nem rendelkezik, olvasóinkat átirányíthatjuk a megfelelố helyre. Ezzel szemben a pártok és a politikusok megpróbálnak mindenre választ adni, így az általuk megadott linkek általában a honlapcsaládon belül maradnak.

10. „Jelenjünk meg a való világban!” Ha blogunk elért egy bizonyos olvasottságot, és sikeresnek mondható, feltétlenül menjünk ki, és a valóságban is mutassuk meg magunkat!

Ez a tanács ebben az esetben elsố pillantásra értelmetlennek túnik, hiszen a miniszterelnök a pozíciójából kifolyólag gyakran szerepel nagy nyilvánosság elốtt, Gyurcsány Ferenc ennek ellenére sikeresen megfogadta. Blogjában többször is említést tesz arról, hogy futással tartja edzésben magát. A jó idó beálltával a Margit-szigeten folytatta tréningjeit, ahová blogjának a látogatóit is invitálta, alkalmat nyújtva arra, hogy megjelenjen olvasói elốtt és mintegy „demisztifikálja” a személyiségét.

11. „Reagáljunk!” Amellett, hogy meghallgatjuk olvasóinkat, reagáljunk is hozzászólásaikra, leveleikre! Ha van rá alkalmunk, feltétlenül használjuk ki az internet adta interaktivitás lehetôségeit; olvasóink meg fogják hálálni.

Ezzel a miniszterelnök is tisztában lehet, hiszen a vizsgált idôszakban bejegyzéseinek majdnem egytizedét a hozzászólásokra való reagálásai tették ki. Ugyanakkor hozzá kell tenni, hogy a teljes kép ennél árnyaltabb, mert a valóságban a reagálások nagy részére a blog kezdetén és a kampány alatt került sor, egyébként ebból a szempontból a kormányfó nemegyszer elhanyagolta olvasóit.

A felsorolt tizenegy tanács megfogadása valóban olvasóbarát blogot hozhat létre. A Gyurcsány-blog idővel nagyrészüket követte, és hozzájárult szerzójének sikereihez, legalábbis saját pártján belül.

\section{Az internetes politikai kommunikáció és a blog}

$$
\begin{array}{r}
\text { „Ostoba gyúlölet az, mi lenéz mindent, ami új, } \\
\text { ám újat imádni csupán - gyưlöletes ostobaság." } \\
\text { római közmondás }
\end{array}
$$

\subsection{Az internetes kampány és a A blog}

Robert Klotz a hagyományos médián és az interneten keresztül folytatott kampányok különbségeit próbálta feltérképezni, és négy jelentôs eltérést talált közöttük (Klotz, 2004: 64). Érdemes megvizsgálni, hogy a blog hogyan illeszkedik be az internetes eszközök sorába, illetve miben tér el más online eszközöktól.

- A véletlenszerï elérés csekély esélyei

Talán ez a legnagyobb különbség az internet és más tömegkommunikációs eszközök között. Amíg újságolvasás, rádióhallgatás vagy televíziózás közben óhatatlanul találkozunk politikai reklámokkal is, az interneten sokkal inkább mi magunk irányítjuk, hogy milyen tartalommal szembesülünk, hiszen ahhoz, hogy eljussunk bármilyen (eset- 
leg politikai) tartalmú közleményekhez, aktív tevékenységre (valamely cím beírására, egy-két kattintásra stb.) van szükség.

Ahogy Klotz is rámutat, ennek megvan a pozitív és a negatív oldala is. Negatív vonásnak tekinthetố, hogy a politikus a honlapjával nem képes tömegeket elérni, a bizonytalan szavazók helyett tehát a biztos támogatókra koncentrál. Megtartani, megerôsíteni és mozgósítani próbálja politikai híveit. Negatívum továbbá az is, hogy bár a bizonytalan szavazókat nem sikerül elérnie, politikai versenytársai számára bepillantást enged kváziprivát szférájába: támadási felületet hoz létre, amit kétségkívül megpróbál minimalizálni. Ezzel szemben pozitívum, hogy minden olvasója -akár a támogatói közé tartozik, akár nem - valamilyen mértékben érdeklódik iránta és kampánya iránt. A honlap az érdeklődók körében tehát sokkal hatékonyabb, hiszen egy televíziós vagy rádiós hirdetés időtartamánál az olvasó többet fog a honlapon eltölteni.

A blog ebben a tekintetben nem hoz semmi újat. Talán csak annyit, hogy ha nem is növeli meg a honlap látogatóinak a számát, rendszeresebbé teheti a látogatásokat. Ez azzal az elốnnyel jár, hogy a naponta visszalátogatók azonnal szembesülnek a legfrissebb fejleményekkel. Ez viszont újabb mozgósítást vagy legalábbis magasabb szintú aktivitást jelent - hiszen az érdeklődóknek naponta el kell indítaniuk a böngészôjüket, és be kell írniuk a kívánt internetes címet. A Gyurcsány-blognak sikerült napi legalább 5-6 ezer embert a www.amoba.hu vonzásában tartani.

\section{- Az üzenetek vételének sorrendjét a címzett határoz:a meg}

A televíziós hirdetésekkel vagy a politikai beszédekkel szemben, melyeknek a felépítését a kampányfőnök vagy a szónok dönti el, az interneten a befogadott üzenetek sorrendje (és mennyisége is) teljes mértékben a felhasználótól függ.

A látogató kényelmét szolgálja, hogy bárhonnan bármikor hozzáférhet a párt vagy jelöltje által közrebocsátott információkhoz, legyen szó akár video-, akár hang- vagy írásos dokumentumokról. Ebból egyenesen következik, hogy az ésszerúen gondolkodó politikus megpróbál megfelelni potenciális támogatói kényelmi igényeinek is. Érdemes tehát minden pártnak és politikusnak a lehetố legtöbb információt feltenni a honlapjára és felszerelni minden kívánatos funkcióval.

Nehézségeket okoz azonban - mutat rá Klotz - éppen az, hogy a honlap készítóje, lévén sosem találkozik a honlap látogatóival, nem tud felkészülni pillanatnyi hangulatukra és reakcióikra. Egy szónok a jelenlévốk hangulatától függően alakíthatja a beszédét vagy legalábbis a beszédstílusát. A honlapok éppen ezért sok esetben megpróbálnak minél kevesebb karakteres stílusjegyet felmutatni és minél semlegesebb hangot megütni, hogy a látogatók legszélesebb körét tudják megszólítani. Ugyanakkor a húvös hangvétel nem a legmegnyeróbb.

A blog jól beleillik ebbe a sémába, hiszen az idôrendben közzétett bejegyzések bármelyike bármikor elolvasható, és a blog hosszabb távon egyben tökéletes archívum is. A blog mégis elsôsorban a szerzôjéról szól, és ennek a pozitív hatása abban nyilvánul meg, hogy az érdeklődő látogatókat sokkal energikusabban tudja megszólítani. A honlap mögül hirtelen egy ember bújik eló.

\section{- A hatalmas interaktivitás lehetósége}

Az internet adta eszközökkel - írja Klotz - a jelölteknek egyrészt újabb lehetôségük nyílik üzenetüket nagy tömegekhez eljuttatni, másrészt az internet egyedi voná- 
sainak köszönhetôen ez fordítva is igaz: tömegek üzenetei juthatnak el a jelölthöz. A jelöltet választóinak meghallgatása segítheti annak megértésében, hogy szavazói táborának mely ügyek fontosak, és emellett a szavazók egymással is társalgást folytathatnak.

A hatalmas interaktivitás praktikus oldala egyben hátrányokkal is jár, ugyanis a párbeszéd lehetôsége bizonyos elvárásokat támaszthat a jelölttel és/vagy pártjával szemben, és ha ezeknek mégsem tud megfelelni, könnyen azt a benyomást keltheti, hogy nem érdeklốdik a saját szavazói bázisa iránt. Bár a közönségtốl érkezố kezdeményezésekre való reagálással nyilvánvalóan meg lehet bízni másokat is, ehhez újabb erôforrások szükségesek, vagyis növekednek a kampány költségei.

A blog esetében szintén viszonylag magas fokú interaktivitás érhető el. A politikus a bejegyzéseivel kezdeményez beszélgetést önmaga és az olvasók, illetve olvasók és olvasók között. A Gyurcsány-blogot bevallottan három ember készíti. ${ }^{4}$ A miniszterelnök szabad perceiben diktafont ragad, és szóban mondja el gondolatait, ezeket egy titkárnő vagy segéd begépeli, majd Keszthelyi András szerkeszti, kiszúri a nyelvtani hibákat, és ha szükségesnek látja, a szerző beleegyezésével átírhat vagy törölhet bizonyos dolgokat. A miniszterelnök közlése szerint erre eddig még nem nagyon volt példa, mivel a saját gondolatait foglalják írásba.

\section{- Végtelen tér és idö}

Végül Klotz szerint az internetes kommunikáció abban tér el a hagyományos médiumoktól, hogy a világháló nyújtotta végtelen tér és idő korlátlan kommunikációra ad lehetôséget - szúrók beiktatása nélkül. Nyilvánvalóan a televízió, a rádió és a nyomtatott médiumok által nyújtott, térben és idóben igencsak korlátozott „,reklámfelületekhez" képest az internet mindkét dimenzióban a lehetố legtöbbet nyújtja. A párt vagy jelölt honlapja lehetôséget biztosít - ahogy a blog is - szúretlen információk közlésére, a média megkerülésére.

A blog - szemben a gigantikus párthonlapcsaládokkal - előállításában olcsó, kezelésében könnyú. A végtelen térnek és idônek köszönhetốen pedig gyakorlatilag egyszeri kiadásról van szó. A fenntartás és a frissítés pedig szinte automatikusan megoldódik az új bejegyzések rendszeres közzétételével. Igaz ez az amoba.hu honlapra és a Gyurcsány-blogra is, amelyek nem tartoznak szorosan a kormánypárt honlapcsaládjához, s így sokkal nagyobb mozgásterük van, mert nem kell idomulniuk a pártszínekhez; erre nem is törekednek, és a külcsín és a tartalom szempontjából egyaránt szabadabbak.

Adott lévén végtelen tér és idô, elvárhatóvá válik, hogy a jelölt egy-egy témában ne csak általánosságokat mondjon, hanem fejtse ki részletesebben, amit gondol róluk. Megint csak meg kell próbálnia a lehetố legjobban kielégíteni a látogatók igényeit, ám ez kétségkívül nehéz feladat.

4 Toller Laci felépüléséért aggódunk. Gyurcsány Ferenc blogján. http://blog.amoba.hu/blog-3.php?oid= T0125a0b73904f965a753ab4babb24eb. (Letöltés ideje: 2006. október 20.) 


\subsection{A Gyurcsány-blog}

A Gyurcsány-blog egyik legszembetúnóbb tulajdonsága, hogy nem kampányblog. Amerikában Dean és Bush blogjai a kampány végeztével elcsendesedtek. Forgalmukat megpróbálták más oldalakra átmenteni, de nem funkcionáltak tovább ugyanazzal az intenzitással, s ezért olvasóikat - a kemény magot leszámítva - rövid idő alatt elveszítették. A magyar miniszterelnök a nehezebb utat választotta: a választások elốtt bő két hónappal kezdett blogolni, de a gyốzelem után nem dólt hátra karosszékében, hanem új elemeket vásárolt diktafonjába, és folytatta - mind a mai napig - a blogolást. Felmerül a kérdés, hogy miért.

Többször említettem, hogy mind a politikai, mind az üzleti blog „megkerüli” a médiát, közvetlenül szól a szavazókhoz, illetve a vásárlókhoz. E mögött az itt vizsgált esetben az áll, hogy a politikusok függenek a médiától, hiszen programjuk és üzeneteik a média közvetítésével jutnak el a közönséghez. A politikát és a médiát - bár hasonló megfontolások alapján - mégis különböző tényezók motiválják. Mindkét szféra a lehetố legnagyobb publikumot, támogatói kört szeretné a magáénak tudni, ugyanakkor a média elsốdleges szempontja - még az úgynevezett „pártközeli” orgánumok esetében is - a közlemények hírértéke, amit a politikusok nem mindig tudnak biztosítani. Ebból következően a webnaplók ideális lehetôséget nyújtanak ahhoz, hogy a politikus - bár csupán egy szúkebb kör számára - a színen maradhasson.

A blogolás - mivel a kommunikáció újszerú eszköze - a választó számára modernséget sugall. Funkcióját betöltve többek között megerósíti a támogatók kemény magját, és folyamatos reklámként is múködik. A választási kampány során nem egy óriásplakát hirdette a miniszterelnök virtuális naplóját („Gyurcsány Ferenc blogja az amoba.hu-n”): ezzel egyszerre tudták reklámozni a viszonylag fiatal „amőbát" (Alapítvány a modern baloldalért), a miniszterelnök blogját és magát a kormányfớt is.

Február elsố heteiben a legnagyobb ellenzéki pártra figyelt a blogoszféra, mindenki kíváncsian várt egy ellenblogot, az ellenzék azonban nem vette fel a kesztyút, kommunikációjukkal megpróbálták a blogot és a blogoszférát is bagatellizálni. Persze bárki joggal feltételezhette, hogy a kormányfó csak a fiatalok megszólítása érdekében kezdett el webnaplót vezetni. ${ }^{5}$ Gyurcsány Ferenc azonban nemcsak elkezdte, hanem folytatta is a blogolást.

A webnapló egyik alapvető sajátossága, hogy lejegyzett formában van, tehát bármikor újra és újra megjeleníthetô. Ezáltal a blog szerzôje akarva-akaratlanul késóbb is szembesül saját gondolataival, érveivel és véleményével. A rendszeres blogolás éppen ezért magabiztosabb írót farag a szerzóból. A miniszterelnök például bevallottan jólesố érzéssel látja, hogy több ezren érdeklődnek mindennapjai iránt, és több százan meg is fogalmazzák az általa közöltekkel kapcsolatos gondolataikat, melyeknek nagy része támogató jellegú. ${ }^{6}$

\footnotetext{
${ }^{5}$ Gyurcsány magnóval blogol. A Fidesz honlapján. http://www.fidesz.hu/index.php?CikkID=50087 (Letöltés ideje: 2006. október 21.)

${ }^{6} \mathrm{Ma}$ leteszi az esküt a kormány. Gyurcsány Ferenc blogján. http://blog.amoba.hu/blog-3.php?oid= T51f499784496a3685928f4b36f8cc83 (Letöltés ideje: 2006. október 19.)
} 
Az üzletemberek és a politikusok egyaránt elsôsorban azért nyúlnak a blogokhoz, mert nagy részük tisztában van azzal, hogy potenciális támogatóik torkig vannak a többszörösen megszúrt és megszerkesztett, üzletileg, illetve politikailag korrekt, ám semmitmondó üzenetekkel. A webnaplók sokkal személyesebb hangvételükkel alternatívát nyújtanak ezekhez: a blogokban emberek beszélnek emberekhez, személyiségek jelennek meg a virtuális térben. Érvek és tapasztalatok kapnak hangot, nem semmitmondó reklámszövegek. Bármely üzleti vállalkozás vagy politikai szerveződés legnagyobb hibája éppen az lenne, ha a már megszokott standardizált marketingstratégiáka próbálná meg átültetni a blogra.

A blogok körül - világszerte - közösségek jönnek létre bizonyos ügyek támogatására. Nyilvánvaló, hogy a honlapok elsốsorban a szimpatizáns közösségnek szólnak, ám ha úgyis csak támogatók látogatják óket, minek fejleszteni bármit is? Az egyesült államokbeli egyik leghíresebb politizáló blog, a DailyKos szerzője szerint: „A marketingipar a véleményvezérekról beszél, igaz? Úgy értem, a sikeres marketing Szent Grálja elérni azt a tíz vagy cirka tíz \%át a társadalomnak, amely a legszenvedélyesebb és/vagy leghozzáértóbb része - bármilyen témáról legyen is szó. Szóval, amikor politikai véleményvezérekról van szó, marketingtanulmányok megmutatták, hogy még befolyásosabbak, mint egyéb társaik, saját témájukban."

A közösségek azonban segítenek abban is, hogy a politikus megismerje az ốt támogató kemény mag véleményét vagy hangulatát. Kipróbálhat új jelszavakat és egyéb kampány-eszközöket is, hiszen ebben a környezetben csak konstruktív kritikával szembesülhet. A miniszterelnök már a negyedik bejegyzését a késóbb jelszóvá vált „Húzzunk bele!” kitétellel fejezte be. Körülbelül két héttel ezután kipróbálta a mérsékeltebb „Tegyük a dolgunkat!” jelszót is, amit késóbb a kampány után, nyáron használt minden bejegyzése végén.

\section{Összegzés}

Mivel a blog az internetes kommunikáció világán belül is viszonylag új eszköz, hatékony felhasználásának a szabályai és törvényszerúségei napjainkban alakulnak ki. Bizonyos dolgokra az egyéb online eszközöknél kevésbé, míg másokra sokkal inkább alkalmas. Például a közösségépítés, a párbeszéd kezdeményezése és a politika humanizálása valamely párt honlapján blogok nélkül szinte megvalósíthatatlan.

A blogok magyar politikai kommunikációban eddig még nem okoztak jelentôs változásokat, egyelőre csak beilleszkedtek a környezetbe. Késóbb azonban minden bizonnyal még hatékonyabban ki fogják egészíteni az online érintkezési formák „fegyvertárát”, és leváltják a kevésbé hatékony eszközöket. Az USA-ban lezajlott események alapján még az is lehetséges, hogy legalább olyan fontos részévé válnak a kampányoknak, mint a mobiltelefonok és honlapok.

Ahhoz azonban, hogy a blog teljes mértékben kifejthesse hatását, egy sokkal magasabb szintú internetpenetrációra van szükség. Kline és Burstein szerint az Egyesült Államok a 2002. év táján éppen hogy elérte azt a „hálózatosodási” szintet, amely már elegendő a politikai propaganda céljára felhasználható hálózati technológiák potenciáljának a kihasználásához - ez a szint pedig ott jelenleg közel 70 \%-os internetpenetrációt 
jelent, ami bó kétszerese a magyarországi értéknek. Az amerikai felmérések ugyanakkor arra is rámutattak, hogy a blogok önmagukban valószínúleg nem fognak „életbe vágó" politikai küzdelmeket eldönteni, de erôsen polarizált politikai légkörben, ami Magyarországra jellemzó, esetleg sorsdöntóek is lehetnek.

Abból, hogy az internetpenetráció jelenlegi alacsony szintjén a blogok még nem fejthetnek ki jelentôs hatásokat, arra a következtetésre is lehet jutni, hogy felesleges foglalkozni velük. A magam részéról mégsem tartom jelentéktelennek sem a Gyurcsányblogot, sem a kérészéletû́ kampányblogokat, hiszen mindezek egy fejlôdési folyamat első mozzanatai. Ugyanakkor félő, hogy a haladás könnyen megrekedhet, ha sem a politikusok, sem választóik nem mutatnak elegendố érdeklốdést az internet iránt, és ha a világhálón böngészố „, hálózati polgárok” száma Magyarországon továbbra is stagnál.

\section{Irodalom}

Kline, David - Burstein, Dan (2005): Blog!: how the newest media revolution is changing politics, business, and culture. New York, CDS Books.

Klotz, Robert J. (2004): The Politics of Internet Communication. Lanham, Rowman and Littlefield Publishers.

Scoble, Robert - Israel, Shel (2006): Naked conversations: How blogs are changing the way businesses talk with costumers. Indianapolis, Wiley Technology Pub.

Stone, Biz (2004) Who let the blogs out? A Hyperconnected Peek at the World of Weblogs. New York, St. Martin's Griffin.

\section{Egyéb források}

A blog-írásról. Gyurcsány Ferenc blogján. http://blog.amoba.hu/blog-3.php?oid= T912507b436e6c84308db65d43491b94 (Letöltés ideje: 2006. október 20.)

Az amoba.hu és a Gyurcsány-blog csoportstatisztikája. A Medián Webaudit honlapján. http://www.webaudit.hu/index.php?content=12 (Letöltés ideje: 2006. október 23.)

European Union Internet Usage and Population Stats. Az Internet World Stats honlapján http://www.internetworldstats.com/europa.htm (Letöltés ideje: 2006. október 23.)

Gyurcsány magnóval blogol. A Fidesz honlapján. http://www.fidesz.hu/index.php?CikkID=50087 (Letöltés ideje: 2006. október 21.)

Ma leteszi az esküt a kormány. Gyurcsány Ferenc blogján. http://blog.amoba.hu/blog-3.php?oid= T51f499784496a3685928f4b36f8cc83 (Letöltés ideje: 2006. október 19.)

Toller Laci felépüléséért aggódunk, Gyurcsány Ferenc blogján. http://blog.amoba.hu/blog-3.php?oid= T0125a0b73904f965a753ab4babb24eb (Letöltés ideje: 2006. október 20.) 